\title{
Fait technique et degré de sens dans l'analyse d'un processus de débitage magdalénien
}

Sylvie Ploux et Claudine Karlin

\section{(2) OpenEdition}

Édition électronique

URL : https://journals.openedition.org/tc/606

DOI : $10.4000 /$ tc. 606

ISSN : 1952-420X

Éditeur

Éditions de l'EHESS

\section{Édition imprimée}

Date de publication : 1 septembre 1994

ISSN : 0248-6016

\section{Référence électronique}

Sylvie Ploux et Claudine Karlin, « Fait technique et degré de sens dans l'analyse d'un processus de débitage magdalénien », Techniques \& Culture [En ligne], 21 | 1994, mis en ligne le 30 décembre 2005, consulté le 29 septembre 2022. URL : http://journals.openedition.org/tc/606 ; DOI : https://doi.org/ $10.4000 /$ tc. 606

Ce document a été généré automatiquement le 29 septembre 2022.

Tous droits réservés 
Fait technique et degré de sens dans l'analyse d'un processus de débitage magdalénien

Sylvie Ploux et Claudine Karlin 